\title{
Stevens-Johnson syndrome-toxic epidermal necrolysis: a fatal cutaneous adverse reaction to oral acyclovir
}

\author{
Subhra Sankar Sen, ${ }^{1}$ Abheek Sill, ${ }^{2}$ Uddalak Chakraborty, ${ }^{3}$ Atanu Chandra (i) ${ }^{3}$
}

'Medicine, Midnapore Medical College, Midnapore, West Bengal, India

${ }^{2}$ Dermatology, Venereology, Leprosy, RG Kar Medical College and Hospital, Kolkata, West Bengal, India

${ }^{3}$ Internal Medicine, RG Kar Medical College, Kolkata, West Bengal, India

\section{Correspondence to}

Dr Atanu Chandra;

chandraatanu123@gmail.com

Accepted 6 August 2020

\section{DESCRIPTION}

An otherwise healthy 26-year-old man presented to the emergency department with fever and generalised rash for the preceding 2 days. He had been prescribed a 7-day course of tablet acyclovir $400 \mathrm{mg}$ (three times per day) for treatment of herpes labialis infection by his local physician. $\mathrm{He}$ commenced to take the medication the following day (day 1). A day later (day 2), he developed fever, malaise, stinging eyes, pain on swallowing and tender skin lesions, which appeared first on the face and spread rapidly to involve the back, trunk and extremities. Subsequently, areas of skin peeling with painful erosion of mucous membrane were noted. He had no known drug allergy, nor was he taking any other drugs (conventional or complementary medicine) apart from acyclovir, which was immediately stopped. On admission (day 5), cutaneous examination revealed dusky-red purpuric macules (many surmounted
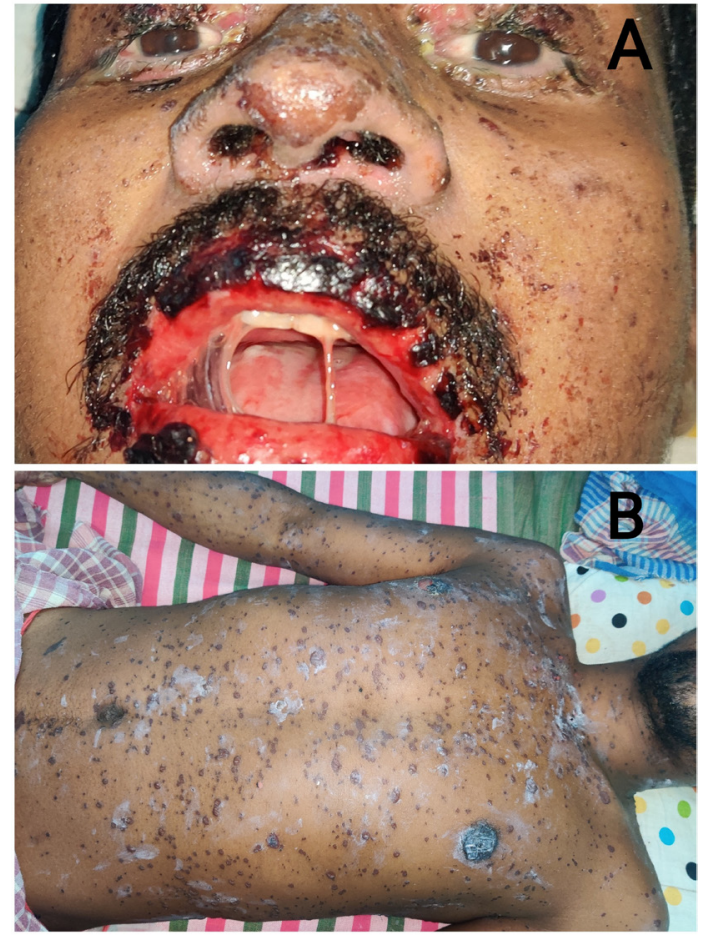

Limited 2020. No commercial re-use. See rights and permissions. Published by BMJ.

To cite: Sen SS, Sil A, Chakraborty U, et al. BMJ Case Rep 2020:13:e238555. doi:10.1136/bcr-2020 238555 Figure 1 (A) Mucopurulent conjunctival discharge, erosions with haemorrhagic crusting involving lips, oral and nasal mucosa, with areas of detached necrotic epidermis over face; (B) Multiple dusky-red purpuric macules surmounted with blisters over the trunk and by vesicles) of various sizes with a tendency to coalesce, involving approximately $25 \%$ of body surface area (figure 1B). Multiple flaccid blisters with positive Asboe-Hansen sign were noted in over the trunk. Positive pseudo-Nikolsky sign was elicited, revealing large areas of raw and bleeding dermis beneath. Mucous membrane involvement, which had preceded the skin eruption, was characterised by painful erosion, haemorrhagic crusting of the lips, oral cavity and mucopurulent conjunctival discharge (figure 1A). Multinucleate giant cells were not visualised on Tzanck smear of blister. Laboratory investigations were notable for raised creatinine, transaminases, leucocytosis and thrombocytopenia. Based on severity of illness score for toxic epidermal necrolysis (score $=3$ ), the mortality risk was estimated to be $35.8 \%$.

Causality assessment was 'probable' according to Naranjo Probability Scale (score $=6$ ) and 'probable/likely' as per the WHO-Uppsala Monitoring Centre criteria. Based on clinical features and temporal association with the drug, a diagnosis of acyclovir-induced Stevens-Johnson syndrome (SJS) was established.

The culprit and all other non-essential drugs were promptly discontinued. He was started on oral cyclosporine $(5 \mathrm{mg} / \mathrm{kg})$ along with adequate supportive care. In spite of vigorous management, his condition progressively worsened (complicated by acute kidney injury, acute respiratory distress syndrome and deteriorating Glasgow Coma Score). He eventually succumbed to the ongoing disease process on day 11.

Acyclovir is a synthetic guanosine analogue which is widely prescribed for herpes simplex and varicella zoster virus infections. It is a potent and highly selective inhibitor of viral DNA polymerase with little side effects on the host. Adverse events like injection site inflammation, phlebitis, bullous reaction, acute renal failure and neurotoxicity have been reported with intravenous acyclovir therapy. ${ }^{1}$ We hereby report a fatal case of SJS and toxic epidermal necrolysis (SJS/TEN), developing in a young adult who was prescribed oral acyclovir.

SJS/TEN represents a rare, potentially lifeextremities. 
suggests it is an immune-driven pathway mediated by granulysin released by drug-specific cytotoxic CD8 T-cells and natural killer cells. ${ }^{3}$ Although any drug can cause SJS/TEN, the usual culprit agents are aromatic anticonvulsants, allopurinol, non-steroidal anti-inflammatory drugs, sulfonamide antibiotics and nevirapine. ${ }^{2}$ Review of literature highlighted two previous reports (none of which had a fatal outcome, unlike

\section{Patient's perspective}

They tried a lot to save my son. They stood by me when I was helpless. They are the real heroes. They did their best. It was my fate that I lost my son. God bless them. - Father of the patient the present case) that incriminated acyclovir as a culprit agent in SJS/TEN. ${ }^{45}$

We highlight an adverse cutaneous drug reaction to a commonly prescribed drug, acyclovir; thereby adding to the expanding list of implicated drugs for SJS/TEN.

Contributors AS contributed to conception, initial drafting of manuscript, critical revision of content and final approval of manuscript. SSS, UC and AC contributed to patient management, conception, critical revision of content and final approval of manuscript. All authors are in agreement to be accountable for all aspects of the work in ensuring that questions related to the accuracy or integrity of any part of the work are appropriately investigated and resolved.

Funding The authors have not declared a specific grant for this research from any funding agency in the public, commercial or not-for-profit sectors.

Competing interests None declared.

Patient consent for publication Parental/guardian consent obtained.

Provenance and peer review Not commissioned; externally peer reviewed.

\section{ORCID iD}

Atanu Chandra http://orcid.org/0000-0002-3809-8926

\section{REFERENCES}

1 Arndt KA. Adverse reactions to acyclovir: topical, oral, and intravenous. J Am Acad Dermatol 1988;18:188-90.

2 Banik B, Bhar D, Sil A. Terbinafine-induced Steven-Johnson syndrome and toxic epidermal necrolysis (SJS/TEN) overlap. Postgrad Med J 2020. doi:10.1136/ postgradmedj-2020-138326. [Epub ahead of print: 14 Jul 2020].

$3 \mathrm{Ng} \mathrm{QX}$, De Deyn MLZQ, Venkatanarayanan N, et al. A meta-analysis of cyclosporine treatment for Stevens-Johnson syndrome/toxic epidermal necrolysis. J Inflamm Res 2018:11:135-42.

4 Fazal BA, Turett GS, Justman JE, et al. Stevens-Johnson syndrome induced by treatment with acyclovir. Clin Infect Dis 1995;21:1038-9.

5 Gungam P, Desireddy P, Namala B, et al. Acyclovir induced Steven Johnson syndrome. Journal of Evidence based Medicine and Healthcare 2015;15:2363-6.

Copyright 2020 BMJ Publishing Group. All rights reserved. For permission to reuse any of this content visit https://www.bmj.com/company/products-services/rights-and-licensing/permissions/

BMJ Case Report Fellows may re-use this article for personal use and teaching without any further permission.

Become a Fellow of BMJ Case Reports today and you can:

- Submit as many cases as you like

- Enjoy fast sympathetic peer review and rapid publication of accepted articles

- Access all the published articles

Re-use any of the published material for personal use and teaching without further permission

Customer Service

If you have any further queries about your subscription, please contact our customer services team on +44 (0) 2071111105 or via email at support@bmj.com.

Visit casereports.bmj.com for more articles like this and to become a Fellow 